\author{
I. Глиняний,
}

аспірант кафедри конституційного права

Національного університету «Одеська юридична академія»

\title{
ВИБОРЧІ ЦЕНЗИ ЯК ЕЛЕМЕНТ ВИБОРЧОГО ПРОЦЕСУ ТА ЯК ЧАСТИНА ГРУНТУВАННЯ ВИБОРЧИХ ТЕХНОЛОГІЙ
}

Виборчі цензи становлять передбачені конституцією чи виборчим законодавством вимоги (умови) щодо осіб для реалізації свого активного чи пасивного виборчого права під час виборчого процесу. Саме ці вимоги до виборців або кандидатів на представницькі посади чи відсутність таких вимог є одним із фундаментів грунтування виборчих технологій.

Під час виборчого процесу громадянам України надається можливість реалізувати своє суб'єктивне та об'єктивне виборче право, до якого законодавець, у свою чергу, закріплює певні вимоги. Вищезазначені вимоги в таких правовідносинах мають великий вплив на будування сучасної демократичної держави, тому що саме вони виокремлюють те коло осіб, яке має право брати участь у формуванні керівних представницьких посад.

Суб'єктивним виборчим правом варто вважати право громадянина брати участь у виборах, а саме: обирати (активне виборче право) та бути обраним (пасивне виборче право). Об'єктивне виборче право в конституційно-правовій науці розглядається як сукупність правових норм, що регулюють порядок організації й проведення виборів як способу комплектації певних складників державного механізму.

Реалізація виборчого права, а отже, і застосування виборчих цензів відбувається в ході виборчого процесу.

Виборчий процес, у свою чергу, становить послідовність подій, сукупність різних форм взаємодії та послідовних дій з висунення, рекламування й голо- сування за суб'єктів політичної влади, персональний i структурний склад яких формується вираженням волі тієї частини населення, яка за законодавством уважається достатньою для визнання результатів виборів легітимними [1, с. 143].

Тобто на виборчий процес впливає не тільки законодавчо закріплені вимоги до такого процесу, а й певні виборчі технології, які відштовхуються від норм і принципів чинного законодавства. Чи відіграє важливу роль виборчий ценз як механізм обмеження 3 боку правового регулювання на виборчі технологіі, які зазвичай мають на меті добитися успіху за результатами виборчого процесу?

Виборчий процес, що має справу з виборчими цензами, можна поділити на певні стадії, які допоможуть з'ясувати роль виборчих цензів як одного 3 найважливіших елементів грунтування демократичної системи нашої держави на прикладі місцевих виборів в Україні.

Першою стадією виборчого процесу, що має справу з виборчими цензами, $€$ формування виборчих дільниць, які поділяються на звичайні та спеціальні. Саме виокремлення спеціальних виборчих дільниць здійснюється залежно від окремого «законодавчого» цензу, фактичного місця знаходження виборця у зв'язку з його станом здоров'я. А саме Закон України «Про місцеві вибори» встановлює, що громадяни України, які знаходяться в стаціонарних закладах охорони здоров'я, включаються до списків виборців на відповідній спеці- 
альній виборчій дільниці та голосують на місцевих виборах за умови, якщо вони мають право голосу на відповідних місцевих виборах. Списки виборців на спеціальних виборчих дільницях складаються не пізніш як за десять днів до дня голосування відповідними дільничними виборчими комісіями на підставі відомостей, поданих не пізніше як за дванадцять днів до дня голосування керівниками стаціонарних закладів охорони здоров'я. У зазначеному поданні вказуються відомості щодо громадян України, які мають право голосу на відповідних місцевих вибоpax i на день проведення цих виборів перебуватимуть у відповідному закладі (ст. ст. 18, 34) [2].

На стадії формування персонального складу виборчої комісії, що здійснює підготовку та проведення відповідних місцевих виборів, Центральна виборча комісія перевіряє, чи відповідають кандидати в члени комісій вимогам ст. 21 Закону України «Про місцеві вибори», а саме їх відповідність цензу громадянства України, вікового цензу (18 років) і цензу осілості (проживають у відповідній адміністративно-територіальній одиниці в межах відповідного територіального виборчого округу та належать до цієї територіальної громади) (ст. 21) [2].

Складання списків виборців як окрема стадія виборчого процесу також оперує критерієм місця проживання виборців, що $є$ процесуальним виборчим цензом.

Наступною стадією виборчого процесу, зміст якої полягає в перевірці відповідності особи виборчим цензам, $€$ реєстрація кандидатів. При цьому до кандидатів у депутати, на посаду сільського, селищного, міського голови, старости не висувається ценз осілості (належності до відповідної територіальної громади), однак з'являється ценз неосудності, представництва політичної партії та «фінансовий» ценз (унесення грошової застави). Так, за ч. 2 ст. 9 Закону України «Про місцеві вибори», депутатом, сільським, селищним, міським головою, старостою не може бути обраний громадянин України, який має судимість за вчинення тяжкого або особливо тяжкого злочину, злочину проти виборчих прав громадян чи корупційного злочину, якщо ця судимість не погашена або не знята в установленому законом порядку (ст. 9) [2].

Незважаючи на змішану (мажоритарно-пропорційну) виборчу систему на місцевих виборах, чинний закон ліквідував інститут самовисування й, отже, встановив новий процесуальний виборчий ценз - представництво політичної партії. Зокрема, у ч. 1 ст. 39 Закону України «Про місцеві вибори» закріплюється, що відповідна територіальна виборча комісія реєструє кандидата в депутати, висунутого місцевою організацією партії в одномандатному виборчому окрузі; а в ч. 1. ст. 40 відповідна територіальна виборча комісія реєструє кандидата на посаду сільського, селищного, міського голови, старости, висунутого місцевою організацією партії (ст. 39, 40) [2].

Згідно зі ст. 44 Закону України «Про місцеві вибори», грошова застава вноситься місцевою організацією партії, яка висунула виборчий список кандидатів у депутати в багатомандатному виборчому окрузі, кандидата на посаду міського голови, або організацією відповідної політичної партії вищого рівня, а також особою, яка висувається кандидатом на посаду міського голови шляхом самовисування, після початку виборчого процесу та до подання документів територіальній виборчій комісії для реєстрації кандидатів у безготівковому порядку, на спеціальний рахунок відповідної територіальної виборчої комісії в розмірі, що є пропорційним до кількості виборців відповідних області, району, міста, району в місті та визначається:

1) для кандидата на посаду міського голови - з розрахунку 4 розміри місячної мінімальної заробітної плати на кожні 100 тисяч виборців відповідного одномандатного виборчого округу; 
2) для виборчого списку кандидатів у депутати Верховної Ради Автономної Республіки Крим, обласної, районної, міської, районної в місті ради, висунутого в багатомандатному виборчому окрузі, - з розрахунку 4 розміри місячної мінімальної заробітної плати на кожні 100 тисяч виборців відповідного багатомандатного виборчого округу.

Центральна виборча комісія на підставі відомостей Державного реєстру виборців станом на перше число місяця призначення чергових, позачергових або перших місцевих виборів визначає розмір грошової застави для кожного багатомандатного, єдиного одномандатного виборчого округу (з виборів міського голови) після призначення чергових, позачергових або перших місцевих виборів, але не пізніше як за 57 днів до дня голосування, невідкладно оприлюднює його на своєму офіційному веб-сайті й інформує про це відповідні територіальні виборчі комісіі. Територіальна виборча комісія протягом чотирьох днів з дня сформування іiі нового складу оприлюднює відомості про розмір грошової застави та спеціальний рахунок, на який вона вноситься, в місцевих друкованих засобах масової інформації, а також невідкладно після відкриття спеціального рахунку передає відомості про нього Центральній виборчій комісії для розміщення на офіційному веб-сайті Центральної виборчої комісії.

Грошова застава повертається відповідному суб'єкту внесення в разі, якщо відмовлено в реєстрації відповідного кандидата, всім кандидатам, включеним до виборчого списку, якщо відповідні вибори визнані такими, що не відбулися, або якщо за результатами місцевих виборів кандидат визнаний обраним міським головою або місцева організація партії, що висунула список кандидатів у депутати, отримала право на участь у розподілі депутатських мандатів. В інших випадках грошова застава не повертається й перераховується територіальною виборчою комісією відповідно до Державного бюджету Укра- їни, бюджету Автономної Республіки Крим, місцевого бюджету [2].

Нарешті, останньою стадією виборчого процесу, пов'язаною з контролем виборчих цензів, є голосування, адже під час проведення голосування на виборчій дільниці два члени дільничної виборчої комісії надають виборцю можливість проголосувати: один член дільничної виборчої комісії за умови пред'явлення виборцем одного з документів (паспорта громадянина Украіни або тимчасового посвідчення громадянина України для осіб, недавно прийнятих до громадянства України), наявності виборця в списку виборців на відповідній виборчій дільниці та наявності в нього права голосу на відповідних місцевих виборах (ураховуючи відмітку в графі «Примітка» щодо постійної нездатності пересуватися самостійно або запису «Голосує за місцем перебування») видає виборчий бюлетень. Разом із тим реально здійснити гарантоване законом волевиявлення громадянам, що працюють на час виборчої кампанії членами та керівниками дільничних виборчих комісій, що проживають в одних виборчих округах, а працюють зовсім в інших, є неможливим.

3 аналізу перерахованих стадій виборчого процесу випливає, що наявність в особи сукупності виборчих цензів є фактичним складом, що слугує підставою для участі у виборчому процесі як виді правовідносин.

3 огляду на вищевикладений виборчий процес, можна дійти висновку, що успішні виборчі технології повинні враховувати критерії та вимоги, які ставляться до кандидатів і виборців, або їх відсутність.

Щоб підтвердити або спростувати цю тезу, необхідно звернутися до визначення поняття «виборчі технології». Наприклад, М. Афанасьєва стверджує, що «виборчі технології - це сукупність прийомів і способів впливу на волевиявлення виборців та результат виборів, які застосовуються при підготовці, організації і проведенні виборчих кампаній 3 метою досяг- 
нення на виборах заданого політичного результату» [3, с. 14].

На прикладі місцевих виборів можна чітко побачити, як ценз осілості в тому чи іншому виборчому округу буде створювати певний напрям для такої виборчої технології, яка матиме на меті досягнення на виборах заданого політичного результату іï кандидата. Наприклад, така політична програма буде прагнути вирішувати проблеми тих потенційних виборців, які ймовірно віддадуть свій голос на користь кандидата, який користується такою виборчою технологію, на основі якої така політична програма створена.

Сучасні виборчі технології - це ще й система факторів і промоційно-прагматичних технологій для формування громадської думки потенційного електорату. Вони виконують такі конститутивні функції:

1) інформаційна - донесення до реципієнтів інформації про основні політичні погляди об’єкта виборчого процесу;

2) конгломеративна - формування єдиного ціннісного поля між кандидатами та їхніми виборцями;

3) освітня - навчання громадськості механізмів правильної поведінки на виборах;

4) модифікуюча - коригування політичних поглядів електорату відповідно до стратегічних пріоритетів кандидатів;

5) маніпулятивна - спекулятивні механізми зміни політичних поглядів електорату;

6) виховна - виховання в аудиторії законослухняності й почуття громадського обов'язку, виборчої культури населення;

7) моніторингова - відстеження громадської думки та політичних уподобань електорату;

8) прогностична - прогнозування результативності виборчого процесу;

9) організаційна - матеріально-фізичне забезпечення виборчого процесу й підрахунку голосів;

10) контролююча - стеження за дотриманням норм законодавчої бази у виборчому процесі [4, с. 144].
При цьому змодельований імідж впливатиме як на свідомість, так і на підсвідомість електорату (в тому числі завдяки нейролінгвістичному програмуванню) зазвичай через психологічно-емоційні важелі виборчих технологій 3 метою формування почуття симпатії до претендента чи антипатії до конкурента [4, с. 144].

Спільною в наведених дефініціях $€$ необхідність визначання адресата (виборця), на формування рішення якого спрямовується та чи інша виборча технологія. Із цим завданням справляється моніторинг. «Його різноспрямований, усеохопний характер, під час виборчого процесу він використовується не тільки як засіб забезпечення прозорих демократичних виборів (якщо мова йде про громадський моніторинг), a i як технологія політичного піару, тобто як інструмент, що забезпечує отримання інформації й переконання цільової аудиторї̈ [5, с. 677]. Моніторинг виборчого процесу використовується 3 метою отримання інформації про цільову аудиторію (тобто про виборців) - інтереси, вподобання, проблеми, антипатії тощо, для відстеження ситуації на різних етапах виборчого процесу 3 метою коригування виборчої стратегії. Без моніторингової діяльності неефективною буде іміджева стратегія претендента на політичну посаду, неможливим стане прогнозування результатів виборів і створення уявлення про позиції політичних суперників [4, с. 133].

Як справедливо зазначає Т. Требик: «У цілому, всі виборчі технології пропагандистського спрямування виходять iз психологічних особливостей масової та індивідуальної аудиторії. Люди по-різному ставляться до політики. Одні беруть активну участь у іï практичній реалізації, інші - індиферентні до неї. Зацікавленість політикою зумовлена багатьма чинниками, такими як вік, стать, соціальне становище, сімейний стан, кланові, національні традиції, інформованість, рівень освіти, культури, інтелекту та ін. Впровадження 
у практику виборчого процесу психологічних виборчих технологій матиме значні переваги для представників владних структур, оскільки дозволятиме тривалий час утримувати владу. У майбутньому широко використовуватимуться різнопланові технології впливу на підсвідомість виборців» [6].

Н. Тугай також наголошує: «Національна і регіональна специфіка ефективного застосування виборчих технологій в Україні обумовлена низкою чинників, серед яких виділяються відповідність технологій інтересам і потребам виборців, а також коректність у визначенні обраної цільової електоральної групи» [7, с. 106].

Отже, під час моніторингу виокремлюються, з одного боку, цільові групи за певною ознакою, яка слугує технологічним виборчим цензом (це може бути вік, стать, професія тощо), з іншого боку, визначаються їхні цільові потреби та інтереси, що є основою для формування передвиборних програм і вибору конкретних виборчих технологій. При цьому технологічні виборчі цензи, як правило, не збігаються 3 нормативними. «У 1920 році вперше жінки мали брати участь у президентських виборах. Бартон робив ставку на цей електорат. Він уважав, що жінки можуть активно голосувати за Куліджа, оскільки зацікавлені в збереженні порядку в краіні, навіть більше, ніж чоловіки. Незадовго стаття про Куліджа з'явилася в жіночому журналі «Woman's Home Companion». Публікація називалася «Message to women» («Звернення до жінок») і була розрахована на те, щоб викликати симпатії Куліджа до жіночої частини електорату» [8, с. 32].

Виходячи із цього, можна зробити висновок, що окремі виборчі технологіï, зокрема моніторинг, спрямовані на виокремлення технологічних виборчих цензів, а інші - вже використовують отримані цензи для формування політичної волі виборців і перемоги на виборах.

Отже, основними технологічними процедурами, що спрямовані на вияв- лення технологічних виборчих цензів і вплив на їх носїв, є соціологічні опитування, оприлюднення рейтингів кандидатів тощо.

Однак є також й інші питання, які виникають під час розгляду виборчих технологій. Наприклад, чи достатньо обмежень або вимог законотворець висунув до кандидатів на представницькі посади? Чи може виборець не підпадати під маніпулювання тими чи іншими виборчими технологіями, опираючись лише на такі основоположні цензи до кандидатів, як ценз осілості, дієздатності, віковий ценз, фінансовий ценз, ценз неосудності тощо. Чи достатньо цих самих критеріїв під час обрання того чи іншого кандидата, щоб виборчі технології не мали «вирішальної» сили, а вирішальна сила залишалася за високопрофесійними, інтелектуальними та ідеологічними якостями кандидата?

Наша держава в теперішній час намагається активно змінювати виборче право, розглядаються пропозиції щодо ліквідування мажоритарної системи під час реалізації виборчого процесу, а також й інші пропозиції, які розглядаються Верховною Радою перед парламентськими виборами до Верховної Ради України, що також вплине на виборчі технології кандидатів, які будуть націлені на успіх у виборчих перегонах.

Виходячи 3 аналізу виборчого процесу на прикладі місцевих виборів України, можна дійти висновку, що без удосконалення вітчизняного виборчого права, насамперед виборчих цензів, виборчі технології будуть і надалі мати потужний вплив на волевиявлення виборців у політичних перегонах кандидатів до бажаних представницьких посад нашої держави. Скасування мажоритарної системи під час реалізації виборчого права має стати лише першим кроком у вдосконаленні сучасного виборчого законодавства. Політична еліта нашого суспільства повинна формуватися на професійних, моральних, культурно-етнічних перегонах серед кандидатів на такі посади, а не виключно на рекламу- 


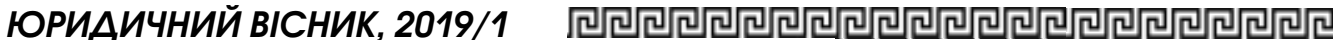

ванні емоційно гострих лозунгів і маніпулюванні психологічно-негативних настроїв виборців до тої чи іншої проблеми без підтвердження професійних якостей кандидата для реального гарантування ї вирішення на тій чи іншій представницькій посаді.

Ключові слова: виборчі цензи, виборчий процес, виборчі технології, суб’єктивне виборче право, об'єктивне виборче право, стадії виборчого процесу, виборче право.

Статтю присвячено виборчим цензам, які на прикладі місцевих виборів України розглядаються як орієнтир для грунтування виборчих технологій. Проаналізовано стадії виборчого процесу, розглянуто поняття виборчих технологій $i$ ix роль у суспільстві. Розглянуто $i$ проаналізовано виборчі чензи з урахуванням їх впливу на виборчі технологї.

Статья посвящена избирательным иензам, которые на примере местных выборов Украины рассматриваются как ориентир для основания избирательных технологий. Проанализировань стадии избирательного проиесса, рассмотрено понятие избирательных технологий и их роль в обществе. Рассмотрены и проанализировань избирательнье иензы с учетом их влияния на избирательные технологии.

The article is devoted to electoral qualifications, which, on the example of the local elections of Ukraine, are considered as a guideline for the foundation of electoral technologies. The stages of the electoral process are analyzed, the concept of electoral technologies and their role in society are considered. The election qualifications were considered and analyzed with regard to their impact on electoral technologies.

\section{Література}

1. Полішук I. Виборчий процес як детермінанта сучасної політики. Політ менеджмент. 2005. № 3. С. 137-146.

2. Закон України про місиеві вибори від 2015 рокy. URL: https: / / zakon.rada.gov.ua/ laws / show/595-19.

3. Афанасьева М.В. Конституиійно-правове забезпечення виборчих технологій в Україні : автореф. дис. ... канд. юрид. наук : 12.00 .02 / кер. роботи М.П. Орзіх ; Нац. ун.-т «Одеська юридична академія». Odeca, 2004. 20 c.

4. Супрун B.М., Супрун В.М. Сучасні виборчі технології в інформаційно-комунікаційній системі: особливості й функції. Матеріали наукової конференцї за підсумками науково-дослідної роботи за період 2015-2016 рр. (15-18 травня 2017 р.) : у 2 m. Вінниця : Донецький національний університет імені Василя Cmуса, 2017. T. 2. C. 142-144.

5. Kaid L.L. Encyclopedia of Political Communication / Lynda Lee Kaid, Christina Holtz-Bacha. Thousand Oaks, CA : Sage Publications, 2008. 1104 p.

6. Требик T.О. Сучасні вибориі технології та їх психологічне спрямування. URL: http: / / www.rusnauka.com / $33_{-}$ NIEK_2008/Politologia / 37482.doc.htm.

7. Тугай H.O., Гречко I. Сучасні виборчі технології та їх застосування під час менедженту виборчої кампанії. Освіта, наука та виробництво: розвиток $i$ перспективи : матеріали I Всеукраїнської науково-методинної конференції, м. Шостка, 21 квітня 2016 р. Суми : СумДУ, 2016. С. 106-107.

8. Зельман О.М. Вибориі технології та політична реклама як інструмент становлення політичного лідера. Грані. Політологія. 2016. № 1 (129). С. 30-34. 